\title{
Gereja dan Gerakan Anti Vaksin: Sebuah Kajian Netnografi Komunitas Keagamaan Virtual
}

\author{
Bakhoh Jatmiko \\ Sekolah Tinggi Theologia Nazarene Indonesia \\ djatcair@sttni.ac.id
}

\section{D01: https://doi.org/10.34307/b.v4i2.293}

\begin{abstract}
The development of technology has created a new space for social interaction mediated by the internet (computer-mediated communications). Space which built on an agreement and shared understanding among the members. The author conducted research on virtual religious group expressing an opposite opinion to the general beliefof the church, namely rejects COVID-19 vaccines. This research aims to find the religious reasons behind their exception on the COVID-19 vaccine. The research method applied in this study is qualitative with the netnography research approach. This approach was conducted to study culture and online community (cyberspace) using social interaction mediated by computer/internet. After underwent sets of research procedures, the author found the religious argumentations used to reject the vaccine, namely: the cares of an adverse effect of the vaccine; hesitancy of vaccine test procedures; moral and ethical objection; an intact of faith expression; religious - apocalyptic mindset; and the belief of global elite conspiracy.
\end{abstract}

Keywords: Anti Vaccine, COVID-19, Netnography, Antichrist, Global Elite

\begin{abstract}
Abstrak: Perkembangan teknologi telah menciptakan ruang interaksi sosial baru yang dimediasi oleh internet (computer mediated communications). Ruang ini dibangun atas kesepakatan maupun kesepahaman antar anggotanya. Penulis melakukan penelitian terhadap kelompok virtual keagamaan yang mengungkapkan pemikiran yang berlawanan dengan keyakinan gereja pada umumnya, yaitu menolak vaksin COVID-19. Riset ini bertujuan untuk menemukan alasan-alasan keagaaman dibalik penolakan mereka terhadap vaksin COVID-19. Metode Penelitian yang digunakan di dalam kajian ini adalah kualitatif dengan pendekatan netnografi. Pendekatan ini dilakukan untuk mempelajari budaya dan komunitas daring (cyberspace) yang memanfaatkan interaksi sosial yang termediasi oleh komputer/internet. Setelah melewati serangkaian prosedur penelitian, penulis menemukan argumentasi-argumentasi keagamaan yang digunakan untuk menolak vaksin, yaitu: kekhawatiran terhadap efek negatif vaksin, keraguan dalam prosedur uji vaksin, keberatan moral dan etis, ekspresi iman yang utuh, pola pikir religious - apokaliptik, dan keyakinan tentang konspirasi elit global.
\end{abstract}

Kata Kunci: Anti Vaksin, COVID-19, Netnografi, Antikris, Elit Global

\begin{tabular}{llll}
\hline Article History : & Received: 19-07-2021 & Revised: 17-11-2021 & Accepted: 24-11-2021
\end{tabular}

\section{Pendahuluan}

Era digital dan berkembangnya teknologi informasi berbasis internet menghadirkan budaya interaksi, sosialisasi dan komunikasi yang baru. Ruang siber (cyberspace) menjadi ruang yang diciptakan dan dihuni oleh sekelompok masyarakat digital untuk 
menyuarakan ketidaksepahaman tetapi sekaligus mencari kesepahaman yang tidak ditemukan di ruang nyata. Hal ini yang terjadi di dalam penggunaan media sosial secara khusus facebook yang dijadikan sebagai kanal ekspresi keyakinan, bertukar pikiran dan menemukan orang-orang yang sepaham. Penulis melakukan pengamatan terhadap grup facebook X yang memiliki lebih dari 1000 anggota dengan pendekatan netnografi. Dari pengamatan yang dilakukan, penulis menemukan bahwa anggota grup tersebut adalah pemeluk agama Kristen (Kristiani). Mereka secara aktif melakukan aktivitas digital yang berisi pemikiran berbeda dengan keyakinan mainstream gereja terkait dengan upaya vaksinasi dan pandemi COVID-19.

Vaksin dinilai sebagai sebuah pencapaian besar di dalam dunia kesehatan di abad 21. Namun di sisi lain, tidak semua pihak serta merta dapat menerima vaksin sebagai upaya preventif terhadap penyakit dan epidemik tertentu. Alasan keagamaan menjadi salah satu predictive factor yang dominan terhadap sukses atau tidaknya vaksinasi setiap kali terjadi sebuah pandemi. ${ }^{1}$ Berbagai penelitian menunjukkan bahwa keyakinan agama menjadi faktor kedua dari keputusan menolak atau menerima vaksin setelah alasan kesehatan, yang kemudian disusul alasan sosial, lalu alasan filosofis yang mencakup keyakinan pribadi maupun keberatan nurani. ${ }^{2}$

Di dalam konteks kehidupan bergereja, perdebatan di dalam mahzab-mahzab yang ada di dalamnya mengenai vaksin telah melewati sejarah yang panjang. Misalnya, kelompok Protestan Ortodoks (Ortodox Protestant Denomination - OPD) menyatakan sikap yang tegas mengenai penolakkannya terhadap vaksinasi sejak abad ke-19 dengan melihat vaksin sebagai kekebalan artifisial dan bahan asing yang merusak citra Allah dalam diri manusia. ${ }^{3}$ Penolakan terhadap vaksin di kalangan Kristen Protestan juga sering kali dikaitkan dengan aliran Anabaptis. Aliran ini mengajarkan untuk menjauhi dan menutup diri dari "perkara duniawi" (Closed Religious Community - CRCs) yang mengancam gereja dan komunitas mereka. ${ }^{4}$ Berkaitan dengan penelitian terbaru di masa pandemi COVID-19, Stein dan kawan-kawan menyebutkan bahwa tingkat kematian di dalam komunitas ini terus menerus mengalami peningkatan yang patut diduga berkaitan

1 Gordana Pelčić et al., "Religious Exception for Vaccination or Religious Excuses for Avoiding Vaccination," Croatian Medical Journal 57, no. 5 (2016): 14-16; Wilhelmina Lm Ruijs et al., "How Healthcare Professionals Respond to Parents with Religious Objections to Vaccination: A Qualitative Study," BMC Health Services Research 12, no. 1 (2012).

2 Centers for Disease Control and Prevention(CDC)., "Vaccination Coverage among ChilDren in Kindergarten-United States, 2011-12 School Year," MMWR Morb Mortal Wkly Rep. 61, no. 33 (2012): 647-652; Hodge JG and Gostin LO., "School Vaccination Requirements: Historical, Social, and Legal Perspectives ," KY Law J. 90, no. 4 (2002): 831-890; Omer SB et al., "Non-Medical Exemptions to School Immunization Requirements: Secular Trends and Association of State Policies with Pertussisincidence," JAMA 296, no. 14 (2006): 1757-1763; Omer SB et al., "Vaccine Refusal, Mandatory Immuni-Zation, and the Risks of Vaccine-Preventable Diseases.," N Engl J Med 360, no. 19 (2009): 1981-1988; Omer SB et al., "Vaccination Policies and Rates of Ex-Emption from Immunization, 2005-2011," N Engl J Med. 367, no. 12 (2012): 1170-1171.

3 Wielders CC et al., "Mumps Epidemic in Orthodox Religious Low-Vaccination Communities in the Netherlands and Canada, 2007 to 2009," Euro Surveill 16, no. pii (2011): 19989-undefined.

${ }^{4}$ D. B. Kraybill, The Riddle of Amish Culture (Johns Hopkins University Press, 2001). 
dengan keyakinan kutural religius dari kelompok ini. ${ }^{5}$ Sementara itu, isu tentang keberatan penggunaan vaksin sebagai bagian dari upaya kesehatan juga pernah disuarakan oleh gereja Katolik. Pada tahun 1980an komunitas Katolik di 60 negara pernah menyuarakan penolakan terhadap penggunaan vaksin tetanus yang dituangkan dalam Pontifical Academy for Life. Pernyataan tersebut berkaitan dengan isu moral dan etis dalam riset maupun pengembangan vaksin yang melibatkan galur sel (cell lines) janin manusia yang diaborsi. ${ }^{6}$

Sementara itu, penolakan terhadap vaksin juga sering dilatarbelakangi oleh keyakinan religius-apokaliptik pada komunitas keagamaan yang mengakar pada pola pikir Judeo-Christian. Bagi ini, vaksin dikaitkan dengan pekerjaan antikristus yang akan datang di akhir zaman dengan menyesatkan manusia. ${ }^{7}$ Sementara itu, di dalam konteks modern, Jolley dan Peterson mengungkapkan terdapat perkembangan pemikiran apokaliptik hibrid antara tradisional dan modern. ${ }^{8}$ Mereka meyakini bahwa vaksin adalah produk antikris untuk mengendalikan manusia dengan mengubah DNA maupun sistem gelombang elektromagnetik yang menggunakan teknologi $5 \mathrm{G}$ sebagai tanda dimulainya gerakan New World Order. ${ }^{9}$

Perkembangan teknologi digital dan media informasi berbasis internet tidak menghentikan gerakan penolakan terhadap vaksin. Pelčić dan kawan-kawan menemukan bahwa gelombang penolakan terhadap vaksin mengalami eskalasi yang signifikan justru di belahan dunia barat yang erat dengan kemajuan teknologi. ${ }^{10}$ Arus data yang begitu cepat membuat pemikiran dan keyakinan tentang anti vaksin menyebar dengan sangat cepat. Akibatnya, keberatan terhadap vaksin tidak hanya berkaitan dengan mahzab tertentu di dalam gereja, atau closed religious community tertentu, namun memenuhi ruang-ruang interaksi sosial di dunia maya.

Penulis menemukan adanya pemanfaatan media sosial, khususnya facebook untuk menjadi ruang ekspresi pemikiran yang berbeda dengan keyakinan arus utama. Hal ini menimbulkan pemikiran, mengapa di tengah arus utama gereja yang mendukung program vaksinasi COVID-19 terdapat riak yang memiliki keyakinan sebaliknya? Dalam pendekatan observasi partisipatif di dalam sebuah grup maupun in depth interview kepada beberapa pemilik akun, penulis menemukan ada anggota-anggota yang menyampaikan sikap mereka dengan mengajukan berbagai argumentasi keagamaan

\footnotetext{
${ }^{5}$ Rachel E Stein et al., "Closed but Not Protected : Excess Deaths Among the Amish and Mennonites During the COVID - 19 Pandemic," Journal of Religion and Health, no. 0123456789 (2021).

${ }^{6}$ Heidi Larson, "Underlying Issues Are Key to Dispelling Vaccine Doubts," Bulletin of the World Health Organization, February 2014.

7 Blessing Nyahuma and Joachim Kügler, "Apocalypse Then and Now! - Political and Religious Interpretations of Tribulations in Apocalyptic Mind-Sets," Pharos Journal of Theology 102 (2021).

8 Daniel Jolley and Jenny L. Paterson, "Pylons Ablaze: Examining the Role of 5G COVID-19 Conspiracy Beliefs and Support for Violence," British Journal of Social Psychology 59, no. 3 (2020): 628-640. ${ }^{9}$ Ibid.

${ }^{10}$ Pelčić et al., "Religious Exception for Vaccination or Religious Excuses for Avoiding Vaccination."
} 
bercorak Kristen. Tujuan dari penelitian ini adalah untuk menemukan alasan-alasan keagamaan dibalik penolakan mereka terhadap vaksin COVID-19. Penelitian ini dilakukan untuk menjawab pertanyaan penelitian: "Pemikiran-pemikiran keagamaan apa sajakah yang melatar belakangi gerakan anti vaksin di kalangan pengguna facebook Kristiani?

\section{Metode Penelitian}

Penelitian yang digunakan di dalam kajian ini adalah penelitian kualitatif dengan pendekatan netnografi. Metode penelitian ini diperkenalkan oleh Robert Kozinets yang awal mulanya digunakan untuk riset pasar dan marketing produk. Secara sederhana, netnografi dimengerti sebagai metode riset kualitatif yang merupakan pengembangan dari riset etnografi guna mempelajari budaya dan komunitas daring (cyberspace) yang memanfaatkan interaksi sosial yang termediasi oleh komputer/internet (computer mediated communications). ${ }^{11}$ Beberapa istilah yang merujuk pada metode ini adalah adalah webnografi, virtual etnografi, digital etnografi, cyber antropologi. ${ }^{12}$

Penelitian ini mengikuti prosedur dan tahapan metodologis yang direkomendasikan oleh Kozinets. ${ }^{13}$ Pertama, Entrée: Peneliti "masuk" dan menjadi anggota grup X di media sosial facebook. Grup ini dibuat pada tanggal 16 April 2020 dan telah memiliki anggota 1.037 anggota yang beragama Kristiani (Protestan dan Katolik). Sebagai bagian dari etika penelitian, peneliti memperkenalkan diri dan meminta ijin kepada admin grup untuk melakukan riset dengan berkomitmen untuk mentaati semua peraturan grup, berlaku sopan, menghargai pendapat setiap anggota dan tidak memicu perdebatan. Kedua, koleksi data: Peneliti melakukan pengamatan terhadap lalu lintas informasi (data) di dalam grup dan juga terhadap perilaku anggota grup khususnya anggota yang memiliki engagement yang tinggi dan mendapat banyak respon dari anggota yang lain. Dari proses observasi partisipatif, peneliti menyalin data-data hipermedia kedalam arsip penelitian peneliti. In depth interview juga dilakukan terhadap anggota yang grup yang memiliki traffic yang tinggi di dalam grup. Wawancara dilakukan dengan menggunakan fitur FB Messager secara pribadi. Verbatim wawancara didokumentasikan berdasarkan narasumber yang nantinya akan dianalisa di tahap selanjutnya. Untuk memperkuat kajian dalam memastikan saturasi data, peneliti juga masuk dalam grup whatsapp yang dikelola oleh admin yang sama dan sebagian anggotanya merupakan anggota dari grup yang sedang diteliti.

Ketiga, analisis dan interpretasi: Peneliti mengklasifikasikan hipermedia yang diperoleh berdasarkan format file data tersebut (video, gambar, audio maupun

11 R. V. Kozinets, "The Field Behind The Screen: Using Netnography for Marketing Research in Online Communities," Journal of Marketing Research (2002): 61-72.

12 R. V. Kozinets, Netnography: Doing Etnhograpic Research Online (London: Sage Publication, 2009).

13 Kozinets, "The Field Behind The Screen: Using Netnography for Marketing Research in Online Communities." 
percakapan dalam bentuk teks). Proses koding verbatim dari informan dilakukan dengan menggunakan program atlas.ti versi 9.1. Koding data meliputi proses open coding, axial coding dan selective coding. Open coding dilakukan untuk pengkodean pada transkrip wawancara. Axial coding dilakukan untuk mengkategorikan tema-tema alasan keagamaan yang terungkap di dalam percakapan. Kemudian, selective coding dilakukan untuk mencari dan menentukan kategori kode yang menjadi inti pemikiran dan hubungannya dengan kode-kode lain yang ditemukan.

\section{Hasil dan Pembahasan}

\section{Gerakan Anti Vaksin di Ruang Virtual}

Pandemi COVID-19 dan vaksinasi memiliki varian persepsi di tengah-tengah masyarakat. Tidak semua ada di halaman yang sama untuk melihat pandemi ini sebagai wabah global dan menerima vaksin sebagai "antidote" dari virus ini. Seperti dilansir oleh kompas.com, Doni Monardo sebagai ketua Gugus Tugas Percepatan Penanganan COVID-19 mengatakan bahwa ada masyarakat Indonesia yang meyakini bahwa pandemi ini adalah sebuah rekayasa dan konspirasi. ${ }^{14}$

Pernyataan sikap masyarakat ini juga terekspresi di dalam ruang-ruang digital dan berbagai jejaring sosial. Riset terbaru dari Media Survei Nasional (Median) kepada 1.089 pengguna facebook menemukan bahwa sebanyak 38,6 persen responden menyatakan ragu-ragu terhadap vaksin. Kemudian sebanyak 7,1 persen menyatakan tidak percaya, dan 3,2 di antaranya sangat tidak percaya. ${ }^{15}$ Kendati tingkat kepercayaan masyarakat Indonesia mengenai vaksin semakin meningkat berdasarkan survei Universitas Maryland dan facebook; ${ }^{16}$ namun masih terdapat ruang-ruang sosial yang memiliki keengganan untuk menerima vaksinasi seperti temuan penulis di dalam kajian berikut ini. Dari hasil penelitian yang dilakukan di grup facebook X yang teridentifikasi sebagai grup virtual keagamaan, para anggotanya mengindikasikan penolakan terhadap vaksin dengan berbagai alasan yang terungkap dalam pembahasan berikut.

\section{Identifikasi Grup X sebagai Komunitas Virtual Keagamaan}

Setiap komunitas interaksi sosial di berbagai jejaring sosial pada umunya dibentuk berdasarkan kesepakatan yang didasari persamaan-persamaan yang dimiliki oleh pendiri maupun anggotanya. Seperti yang disampaikan oleh Ahmad Toni, komunitas media daring seperti grup facebook terbentuk berdasarkan persamaan tujuan; dan satu

\footnotetext{
${ }^{14}$ Rakhmat Nur Hakim, "Gugus Tugas: Masih Ada Masyarakat Percaya COVID-19 Konspirasi," Kompas.Com, last modified 2020, accessed July 9, 2021.

15 Febrianto Adi Saputro, "Survei: 51,1 Persen Masyarakat Indonesia Percaya Vaksin | Republika Online," Republika.Com, last modified 2021, accessed July 9, 2021.

16 Dwi Hadya Jayani, "Orang Indonesia Makin Percaya Vaksinasi COVID-19 - Infografik Katadata.Co.Id," Katadata.Co.Id, last modified 2021, accessed July 9, 2021.
} 
diantaranya adalah tujuan keagamaan. ${ }^{17}$ Di ruang-ruang sosial virtual seperti inilah anggota menggungkapkan minat, bertukar ide, berbagi informasi, saling berdiskusi bahkan mengekspresikan kebebasan berpendapat dan keyakinan yang berbeda dengan pendapat dan keyakinan pada umumnya.

Pengamatan partisipatif yang dilakukan oleh penulis di dalam Grup X menemukan beberapa hal yang menjadi catatan penting di dalam riset ini. Pertama, grup ini adalah grup keaamaan yang dikelola oleh dua orang admin berbeda. Grup ini bersifat tertutup dan rahasia. Untuk menjadi anggota grup, akun calon anggota harus diverifikasi oleh pertanyaan verifikatif dan juga oleh ijin dari admin grup. Pertanyaan verifikasi yang diajukan sebagai syarat keanggotaan sangat dogmatis dan mengikat, sehingga dapat dipastikan jika calon anggota tidak memiliki kesamaan keimanan dan keyakinan akan mengurungkan niatnya. Kedua, dari hasil pengamatan penulis; meskipun grup ini tidak memiliki deskrepsi yang jelas tentang identitas keagamaannya, namun simbol-simbol komunikasi yang digunakan menunjukkan bahwa grup maupun anggota grup berafiliasi pada kelompok keagamaan tertentu.

Tabel 1. Visual Netnografi

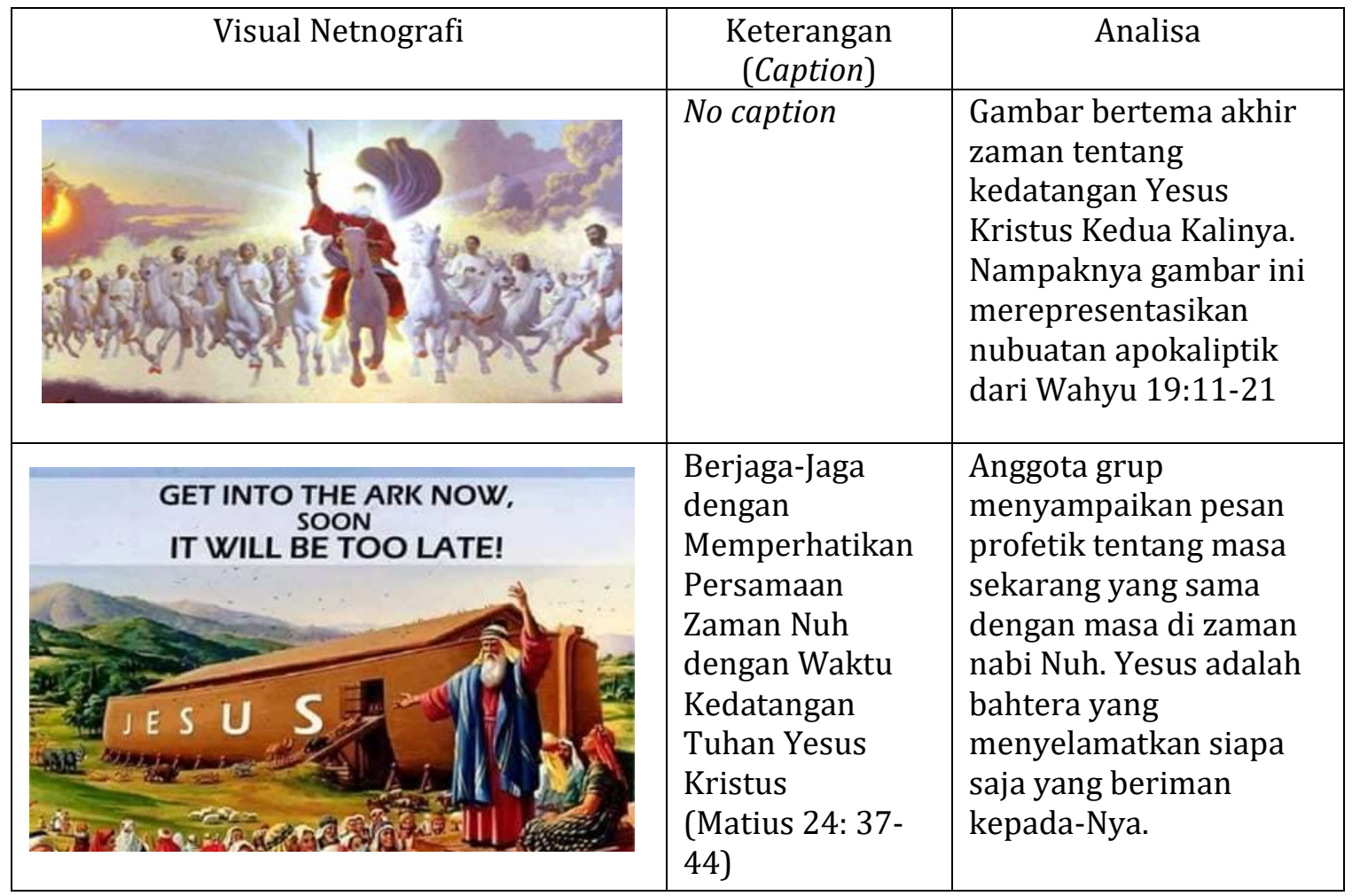

${ }^{17}$ Ahmad Toni, “Studi Netnografi 'Komunitas Anti Islam' Di Media Online Facebook,” in Prosiding SNaPP2017 Sosial, Ekonomi, Dan Humaniora, 2017, 127-138. 


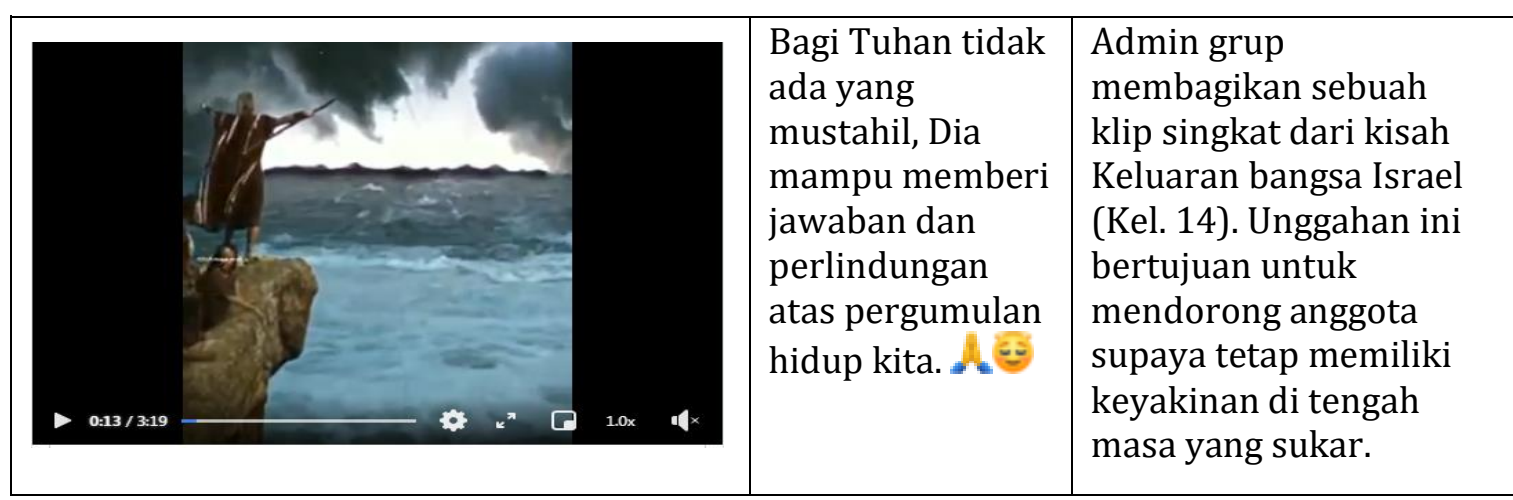

Beberapa data di atas menunjukkan bahwa anggota grup cenderung homogen dalam latar belakang keyakinan dan saling mendukung satu dengan yang lain. Afiliasi keagamaan anggota grup tercermin dalam penggunaan istilah-istilah yang khas, konsep teologi, nukilan ayat dan tipe informasi yang terbaca dalam lalu lintas transaksi data di grup. Temuan ini memenuhi tujuan penelitian untuk menemukan komunitas virtual keagamaan, khususnya Kristiani. Hal ini juga akan mempermudah dalam menentukan kajian terhadap fokus pemikiran dari kelompok yang sedang diteliti.

\section{Tema-tema terkait Penolakan terhadap Vaksin}

Proses analisa data dan serangkaian prosedur yang telah dijalankan menghasilkan temuan yang terkait dengan tema-tema pokok yang melatar belakangi keberatan terhadap vaksin dari kelompok ini. Tidak seperti sejarah anti vaksinasi di masa-masa sebelumnya; penolakan vaksin di dalam kelompok keagamaan di ruang virtual yang diteliti ini memiliki pola pemikiran yang lebih kompleks. Proses axial coding dan selective coding menunjukkan kaitan dan percabangan serta percampuran tema yang satu dan yang lainnya. Keterpisahan tema yang satu dan yang lainnya hampir tidak nampak. Ada garis-garis hubungan antara alasan keengganan yang satu dengan yang lainnya.

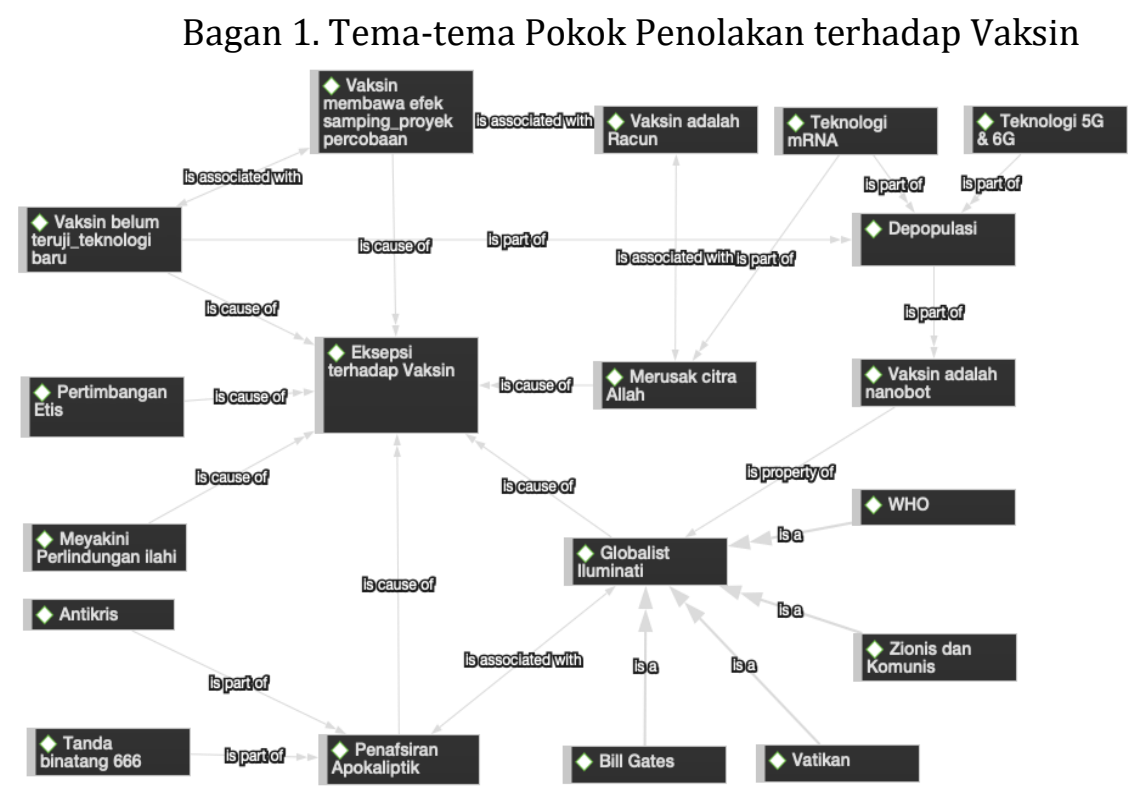


Proses dan analisa data yang dikumpulkan dari lapangan menemukan beberapa tema yang menjadi alasan kunci terkait dengan pemikiran anti vaksin COVID-19 dari kelompok yang diteliti. Beberapa tema tersebut terkait dengan kekhawatiran terhadap efek samping vaksin, keraguan dalam proses uji vaksin, keberatan terkait dengan pertimbangan etis, ekspresi iman yang utuh terhadap perlindungan Allah, pola pikir religious - apokaliptik, pemikiran tentang konspirasi global, dan konsep tentang vaksin yang akan merusak citra diri Allah.

\section{Kekhawatiran Terhadap Efek Negatif Vaksin}

Salah satu alasan keberatan terhadap vaksin COVID-19 yang terungkap di dalam kelompok virtual keagamaan yang ditemukan adalah terbersitnya kekhawatiran terhadap dampak negatif maupun Kejadian Ikutan Pasca Imunisasi (KIPI) atau Vaccine Adverse Reaction (VAR). Efek negatif vaksin menjadi isu yang banyak diperbincangkan di dalam grup. Lalu lintas yang tinggi mengenai informasi mengenai terjadinya KIPI dan pemikiran akan side effect dari vaksin hingga kasus terjadinya kematian mengungkapkan fakta bahwa hal ini menjadi perhatian kelompok yang sedang diteliti.

Dari hasil analisa penulis, domain kekhawatiran tidak hanya pada KIPI yang berkisar pada gejala-gejala klinis saja; melainkan juga berkaitan dengan isu genetik bahkan spiritualitas. Tabel di bawah ini merupakan ringkasan dari area-area kekhawatiran yang dijadikan sebagai alasan penolakan terhadap upaya vaksinasi.

Tabel 2. Kekhawatiran terhadap Efek Vaksinasi

\begin{tabular}{|c|c|c|}
\hline Area Terdampak & Waktu & Contoh \\
\hline Faal & Kini & $\begin{array}{l}\text { Kejang, lumpuh, ruam, melepuh, } \\
\text { impotensi, stroke, kanker, tumor, } \\
\text { gangguan darah, aborsi spontan, } \\
\text { kebutaan, gangguan pernafasan, } \\
\text { gangguan syaraf, peristiwa trombolitik, } \\
\text { kematian }\end{array}$ \\
\hline Genetik & Nanti & Kerusakan DNA, mutasi gen \\
\hline Spiritual & $\begin{array}{ll}\text { Kini dan } \\
\text { nanti }\end{array}$ & $\begin{array}{l}\text { Kehilangan kepekaan terhadap hadirat } \\
\text { Allah, mewarisi gen lucifer, tidak } \\
\text { mengalami rapture, } \\
\text { keselamatan }\end{array}$ \\
\hline
\end{tabular}

Data kualitatif di atas mengungkapkan nilai di balik fenomena penolakan terhadap vaksin di dalam kelompok keagamaan yang sedang diteliti. Pengalaman dan kejadian pada sebuah kasus tertentu dijadikan sebagai rujukan bahkan keyakinan untuk berkeputusan. Analisa dan upaya mencari keterhubungan ilmiah serta teologis telah melahirkan pemikiran-pemikiran dan keyakinan akan dampak negatif dari seseorang yang menerima vaksin. 


\section{Keraguan dalam Prosedur Uji Vaksin}

Keengganan kelompok ini untuk menerima vaksin juga dilatarbelakangi oleh alasan yang terkait dengan proses uji vaksin sebelum didistibusikan. Keengganan ini berkaitan dengan kecukupan uji klinis vaksin COVID-19. Mereka mengungkapkan bahwa vaksin COVID-19 diyakini tidak memiliki kecukupan data interim yang membuktikan keamanan dan kemampuan vaksin untuk membentuk antibodi. Dengan kata lain, kelompok ini mempertanyakan overstepping procedure dari vaksin COVID-19 yang pada umumnya dilewati oleh semua vaksin sebelum diinjeksikan kepada manusia.

Presaposisi terkait dengan kelemahan data interim vaksin COVID-19 dibangun dengan logika dan analisa terkait dengan singkatnya proses klinis dalam riset dan pembuatan vaksin ini. Kelompok ini membandingkan berbagai vaksin terdahulu yang memerlukan uji klinis bertahun-tahun dalam pengembangannya dan juga melewati serangkaian prosedur yang panjang dan rumit. Sedangkan, vaksin COVID-19 ditemukan, dikembangkan dan didistribusikan secara masif dalam waktu kurang dari satu tahun.

Hal ini juga dikaitkan dengan efikasi vaksin COVID-19 yang rendah. Rujukan yang digunakan untuk mendukung pemikiran bahwa vaksin COVID-19 sebenarnya belum siap adalah adanya kenyataan bahwa orang yang sudah mendapatkan vaksin dengan dosis lengkap tetap saja bisa terpapar. Keberatan ini juga berkaitan dengan kekhawatiran akan efek samping yang bisa saja ditimbulkan oleh pemberian vaksin. Informan mengungkapkan keengganaanya untuk menerima vaksin berkaitan dengan kemungkinan bahwa justru vaksinasi yang sedang dilakukan adalah "proyek" uji coba vaksin itu sendiri. Temuan ini mengisyaratkan bahwa Emergency Use Authorization (EUA) yang dikeluarkan oleh BPOM belum cukup memberikan jawaban atas keraguan terkait keamanan dari vaksin COVID-19.

Pertimbangan teologis yang mengemuka adalah perlunya hikmat dalam situasi seperti ini. Mengambil pilihan yang belum tentu kebenarannya adalah sebuah tindakan yang mencerminkan keputusan yang tidak bijaksana. Ditambah lagi, pemikiran religious - apokaliptik (akan dibahas kemudian) menghubungkan "kejanggalan” proses uji vaksin sebagai sebuah konspirasi dari oknum antikris yang datang di akhir zaman. Nukilan ayat yang sering dijadikan sebagai dasar argumentasi terkait hal ini adalah Wahyu 13:18 "Yang penting di sini ialah hikmat: barangsiapa yang bijaksana, baiklah ia menghitung bilangan binatang itu, karena bilangan itu adalah bilangan seorang manusia, dan bilangannya ialah enam ratus enam puluh enam."

\section{Keberatan Moral dan Etis}

Pertimbangan etis merupakan salah satu alasan yang menjadi faktor determinan untuk menerima atau menolak vaksin di kalangan gereja yang ada dari waktu ke waktu. Pertimbangan ini biasanya tidak melihat faktor keamanan maupun efikasi vaksin, 
melainkan berfokus pada aspek pertimbangan moral dan etisnya. Temuan dari kajian yang dilakukan penulis mengidikasikan adanya pertimbangan etis terhadap keberatan mereka untuk menerima vaksin. Berdasarkan hasil wawancara kepada salah satu informan yang adalah seorang Katolik; ditemukan bahwa keberatan informan terhadap vaksin berkaitan dengan pengembangan vaksin yang melibatkan cell lines dari janin yang diaborsi. Meskipun, informan juga mengakui tidak semua vaksin COVID-19 menggunakan bahan baku dan kajian riset dengan sel fetus namun ia menyampaikan bahwa program vaksinasi tetap perlu dievaluasi.

Di kesempatan yang sama, informan juga menjelaskan tentang skisma yang sedang terjadi di dalam gereja Katolik terkait dengan penggunaan vaksin di masa pandemi ini. Informan merujuk pada pemimpin-pemimpin gereja Katolik di beberapa negara secara terbuka menyatakan keberatan moral mereka terkait vaksin COVID-19 yang dikembangkan dari cell lines janin yang diaborsi. Rujukan-rujukan yang disampaikan informan telah terkonfirmasi oleh pemberitaan dibeberapa media meanstreams yang penulis temukan. ${ }^{18}$

Informan juga meyakini bahwa pernyataan dari Vatikan dalam Congregatio pro Doctrina Fidei (CDF) ${ }^{19}$ yang dikeluarkan oleh Vatikan pada tanggal 20 Desember 2020 tidak serta merta menghilangkan keberatan moral terkait dengan vaksin COVID-19 yang baik pengujian maupun pengembanggannya memiliki persoalan etis. Informan merujuk pada sikap pemimpin Katolik di Amerika yang merekomendasikan umat untuk tidak menerima vaksin COVID-19 Johnson \& Johnson. Penulis mencoba mengkonfirmasi hal tersebut; dan sesuai ulasan vaticannews.va, Konferensi Uskup Katolik Amerika Serikat dan sedikitnya enam keuskupan lainnya dari dalam negeri, menyampaikan keprihatinan moral, terkait vaksin yang dikembangkan menggunakan galur sel hasil aborsi. ${ }^{20}$

Informan juga menegaskan keyakinannya dengan mengarahkan peneliti kepada salah satu akun facebook menjadi kiblat keberatannya. Dengan pendekatan snowball interviewing technique, penulis mencoba mencari informasi dari pihak yang dirujuk oleh informan. Dari hasil kajian, pemilik akun rujukan juga memiliki keberatan yang sama terkait dengan vaksinasi. Bahkan lebih tegas, akun ini menggambarkan vaksinasi dengan melibatkan sel fetus sebagai praktik kanibalisme modern.

\section{Ekspresi Iman yang Utuh}

Riset yang dilakukan penulis juga menemukan bahwa penolakan terhadap upaya vaksinasi adalah bentuk nyata dari praktik keimanan yang merupakan hasil dari refleksi

${ }^{18}$ Liberty Jemadu, "Vaksin COVID-19 Terbuat Dari Janin Yang Diaborsi, Gereja Australia Menolak," Msn.Com, last modified 2020, accessed July 9, 2021.

19 "COVID: Vatican Says Coronavirus Vaccines 'morally Acceptable' - BBC News," Bbc.Com, last modified 2020, accessed July 10, 2021.

${ }^{20}$ Lisa Zengarini, "US Bishops Express Moral Concern over 'Johnson \& Johnson' Vaccine - Vatican News," Vaticannews.Va, last modified 2021. 
spiritualitas keagamaan yang murni. Iman yang murni adalah iman yang menempatkan Tuhan sebagai satu-satunya pusat dan sumber pertolongan. Tuhan saja yang seharusnya dijadikan sebagai solusi terhadap segala kesulitan umat yang menyembah-Nya. Konsep semacam inilah yang dipegang dan berusaha dipraktikkan oleh komunitas keagamaa ini.

Upaya vaksinasi dinilai sebagai langkah lunturnya iman yang murni karena manusia mulai mengandalkan sarana lain melebihi kuasa dan otoritas Tuhan. Vaksin dinilai telah menjadi ilah manusia modern di masa pandemi ini. Manusia yang menerima vaksin dinilai kurang beriman dan meragukan perlindungan dari Tuhan. Salah satu informan menyampaikan bahwa keputusannya untuk tidak menerima vaksin adalah keputusan rohani karena justru dengan langkah itu, ia mendemonstrasikan keyakinan imannya. Keberatan dengan tema ini juga kait mengait dengan tema-tema keagamaan lainnya. Misalnya, pemikiran apokaliptik keagamaan yang menghubungkan vaksin dengan tanda antikris juga menjadi klaim bahwa menerima vaksin sama dengan meninggalkan keimanan kepada Tuhan.

\section{Pola Pikir Religious - Apokaliptik}

Penolakan terhadap vaksin juga dipengaruhi oleh pemikiran religius-apokaliptik dari anggota grup yang diteliti. Pemikiran Religious - Apokaliptik yang digunakan penulis di dalam bagian ini terkait dengan keyakinan bahwa apa yang terjadi sekarang merupakan penggenapan dari peristiwa, lambang atau simbol dalam kitab-kitab nubuatan dengan sastra apokaliptik (Daniel, Wahyu). Pemikiran ini memberikan pemaknaan pada peristiwa dan fenomena yang terjadi sekarang dalam perspektif eskatologis (akhir zaman). Istilah yang sama juga digunakan oleh Nyahuma and Kügler dalam kaitannya dengan gerakan anti vaksin di Afrika yang dilatarbelakangi oleh keyakinan bahwa vaksin adalah produk anti-Kristus yang muncul di akhir zaman sesuai dengan nubuatan dengan sastra apokaliptik. ${ }^{21}$ Pemikiran ini mengatakan bahwa sesuai dengan nubutan para nabi di dalam Alkitab, akhir zaman sudah dekat, bahkan sudah tiba dengan fenomena dan tanda-tanda yang muncul sekarang ini.

Kelompok keagamaan yang diteliti pada umumnya sepakat bahwa pandemi COVID-19 dan vaksin adalah penggenapan dari teks-teks apokaliptik di dalam Kitab Suci. Hal ini diungkapkan oleh beberapa informan dalam proses wawancara maupun berbagai unggahan di dalam grup yang dikaji. Kelompok ini meyakini bahwa semua yang sedang terjadi merupakan hal yang sudah seharusnya terjadi menjelang akhir zaman; yaitu kedatangan Kristus kedua kalinya ke dalam dunia.

Berbagai diskusi dan percakapan di dalam grup menggunakan istilah-istilah apokaliptik seperti: akhir zaman, tanda binatang, 666, pengangkatan (rapture), pernikahan anak domba, antikris, dll. Bagian kitab yang sering dikutip adalah Daniel

\footnotetext{
${ }^{21}$ Nyahuma and Kügler, “Apocalypse Then and Now!.
} 
maupun Wahyu. Salah satu informan meyakini bahwa yang sedang terjadi sekarang adalah proses penggenapan dari Wahyu pasal 13-16. Lepas dari model penafsiran yang digunakan untuk melihat teks yang dirujuk maupun posisi eskatologis dari informan; peneliti melihat indikasi yang jelas bahwa penolakan vaksin dikaitkan dengan tema-tema akhir zaman.

Keengganan kelompok ini untuk menerima vaksin dikarenakan keyakinan bahwa vaksin adalah "tanda binatang" atau antikris. Tanda binatang ini terkait keyakinan bahwa di dalam vaksin tersebut mengandung nanochip atau microchip yang akan membuat penerimanya secara otomatis menjadi bagian dari antikris. Varian keyakinan terkait dengan "tanda" ini adalah bahwa sebenarnya bukan masalah ada atau tidaknya chip di dalam vaksin; namun vaksin sendiri adalah tanda antikris itu sendiri.

Kelompok ini meyakini bahwa setiap orang yang sudah menerima vaksin, sama dengan meninggalkan Tuhan dan tidak mendapat anugerah keselamatan lagi. Dalam peristiwa pengangkatan gereja (rapture), penerima vaksin akan tertinggal di dunia dan menghadapi kesulitan besar (tribulasi). Vaksin adalah batu uji kesetiaan iman kepada Yesus Kristus satu-satunya Juru Selamat.

Keyakinan apokaliptik ini juga didukung dengan praktik yang bersifat profetis (kenabian) di antara para anggotanya. Unggahan dengan pesan yang isinya pesan dari Tuhan dalam bentuk mimpi, penglihatan ataupun pesan yang diyakini diterima langsung dari Tuhan relatif sering ditemukan. Sebagian besar pesan-pesan itu menegaskan supaya tidak menerima tanda antikris, maupun pesan supaya terus setia sekalipun mengalami pembatasan-pembatasan karena tidak memiliki tanda itu (vaksin).

\section{Pemikiran tentang Konspirasi Elit Global}

Penolakan terhadap vaksin sangat terkait dengan penolakan terhadap pandemi yang sedang terjadi. Kelompok ini tidak sepenuhnya meyakini bahwa virus Corona benarbenar ada (sebagian kecil mempercayai pandemi COVID-19, hanya tidak seserius yang diberitakan). Mereka menyebut apa yang terjadi sekarang sebagai plandemic - sebuah pandemi terencana. Ada pihak yang sengaja merencakan supaya terjadi situasi yang sedemikian ini. Mereka menyebut oknum di balik situasi ini sebagai para elit global, atau globalist; non state actor; maupun kelompok Iluminati. Dari hasil wawancara, nama Bill Gates adalah nama yang paling sering disebut sebagai anggota globalist. Nama yang lain adalah Roschild \& Rockefeller, Vatikan (Paus), WHO, PBB, Zionis dan Komunis.

Keyakinan yang berkembang di antara kelompok ini adalah sebenarnya yang merebak di dunia sekarang bukan virus, namun propaganda ketakutan yang di besarbesarkan sedemikian rupa oleh kelompok globalist. Teror, kecemasan dan ketakutan ini yang membuat imunitas tubuh manusia melemah sehingga lebih mudah sakit dan banyak yang akhirnya meninggal. Dengan kekuasaan yang dimiliki oleh kelompok ini, mereka menguasai berbagai bidang kehidupan termasuk big tech yang memanupulasi media 
penyiaran dan teknologi informasi. Apa yang diberitakan oleh media terkait COVID-19, angka kematian, pandemi global adalah kebohongan yang sengaja dibuat supaya orang takut dan mau menerima vaksin.

Di dalam penelitian yang dilakukan, penulis menemukan model pemikiran hibrid antara teori konspirasi elite global dan pemikiran apokaliptik. Mereka meyakini bahwa para elit global inilah penggenapan perwujudan dari antikris dan agenda besarnya untuk menghadirkan New World Order (NWO). Mereka akan memerintah di akhir zaman sebagai penguasa tunggal di tatanan dunia baru dengan mengontrol semua manusia pada kehendak mereka.

Mereka meyakini paling tidak dua rencana yang akan diwujudkan oleh para elit global dengan agenda vaksinasi yaitu: totally controled population dan depopulation. Teknologi nanochip yang memungkinkan manusia terhubung dan dengan mudah dikendalikan oleh teknologi 5G (mereka meyakini sebagai Penta Gram, lambang lucifer). DNA penerima vaksin akan diubah, kehidupan mereka akan dikendalikan dan dikontrol. Sedangkan agenda kedua adalah depopulasi. Vaksin adalah bioweapon yang akan membuat manusia justru melemah dan mudah terserang penyakit sehingga dalam kurun waktu tertentu akan ada kematian masif di antara manusia yang sudah menerima vaksin.

\section{Merusak Citra Diri Allah}

Temuan terakhir dari penelitian penulis yang terkait dengan penolakan terhadap vaksin adalah pemikiran bahwa vaksin dapat merusak citra diri Allah di dalam manusia. Mereka meyakini bahwa upaya vaksinasi dengan membentuk kekebalan tubuh dengan rekayasa adalah tindakan yang menyalahi kodrat manusia sebagai ciptaan Tuhan yang dirancang dengan sempurna. Keyakinan ini melihat bahwa vaksin adalah bahan artifisial dan bahan asing yang seharusnya tidak diinjeksikan ke dalam tubuh manusia. Imunitas yang terbentuk di dalam tubuh karena proses vaksinasi adalah kekebalan tubuh palsu, yang sudah direkayasa oleh manusia; yang di dalam hal ini menyalahi kodrat ilahi dalam hidup manusia. Vaksinsinasi dinilai sebagai sebuah tindakan yang dengan sengaja merusak tubuh sebagai gambar Allah dengan memasukkan bahan kimia dan zat asing lainnya dan juga sebagai manifestasi dari pekerjaan Iblis yang sengaja merusak ciptaan Allah.

Sekali lagi, pemikiran ini juga bertalian dengan tema pemikiran yang lain. Selain ada indikasi terhadap efek negatif dari vaksin baik jangka pendek maupun jangka panjang, keengganan untuk menerima vaksin juga masih terkait dengan pemikiran apokaliptik maupun teori konspirasi elit global. Namun pada intinya, penolakan terhadap upaya vaksinasi sesuai dengan tema ini adalah intervensi manusia melalui teknologi dan bahan-bahan buatan dalam tubuh manusia adalah hal yang tidak patut di dalam keyakinan teologis. 


\section{Kesimpulan}

Penolakan terhadap vaksin di dalam gereja telah terjadi selama berabad-abad. Sekalipun keberatan tersebut masih ada hingga hari ini, namun karakter kelompok dan alasan keengganan untuk menerima vaksinasi telah mengalami perubahan. Derasnya arus informasi dalam gelombang kemajuan teknologi telah menghilangkan sekat-sekat dimensional konvensional. Keterbukaan informasi ini juga membuat informasi apa saja dapat diakses secara publik. Kebenaran seolah ada di ruang abu-abu dan sangat subyektif tergantung darimana dan siapa yang melihat informasi itu. Di dalam konteks ini, upaya menyatakan keberatan dan penolakan serta mencari persetujuan terhadap apa yang diyakini sebagai kebenaran dicapai dengan proses interaksi, sosialisasi, akulturasi yang terjadi di ruang-ruang digital. Interaksi di dunia maya memiliki kemampuan dogmatisasi yang kuat terhadap pola pikir, keputusan dan tindakan di dunia nyata. Komunitas virtual maupun figur yang dianut (influencer) di jejaring sosial telah terbukti menjadi penentu keyakinan dan keputusan anggota kelompok komunitas di ruang siber ini. Riset yang dilakukan penulis menemukan alasan-alasan keagamaan yang melahirkan sikap anti terhadap vaksin, yaitu: kekhawatiran terhadap efek negatif vaksin, keraguan dalam proses uji vaksin, keberatan moral dan etis, ekspresi iman yang utuh, pola pikir apokaliptik, pemikiran tentang konspirasi elit global. Hal-hal tersebut yang membangkitkan sentimen serta prejudis terhadap kelompok lain yang menerima vaksin.

Sebagai rekomendasi dari kajian ini, penulis melihat pentingnya keterbukaan dialog antar semua pihak (pemerintah, tokoh-tokoh agama dan semua kelompok keagamaan). Dengan jalan ini harapannya akan meruntuhkan stigmatisasi yang kemudian menumbuhkan rasa saling menghargai sekalipun mungkin pada akhirnya akan sepakat untuk tidak sepakat. Tokoh panutan memiliki peran sentral dalam mengarahkan pemikiran dan membentuk keyakinan. Hal ini meninggalkan pekerjaan rumah bagi setiap individu maupun para influencer di jejaring sosial untuk menjunjung tinggi etika dan norma Kristen serta nilai kebenaran dalam bermedia sosial.

\section{Referensi}

Centers for Disease Control and Prevention(CDC). "Vaccination Coverage among ChilDren in Kindergarten-United States, 2011-12 School Year." MMWR Morb Mortal Wkly Rep. 61, no. 33 (2012): 647-652.

Hakim, Rakhmat Nur. “Gugus Tugas: Masih Ada Masyarakat Percaya Covid-19 Konspirasi." Kompas.Com.

Hodge JG, and Gostin LO. "School Vaccination Requirements: Historical, Social, and Legal Perspectives ." KY Law J. 90, no. 4 (2002): 831-890.

Jayani, Dwi Hadya. “Orang Indonesia Makin Percaya Vaksinasi Covid-19 - Infografik Katadata.Co.Id." Katadata.Co.Id.

Jemadu, Liberty. “Vaksin Covid-19 Terbuat Dari Janin Yang Diaborsi, Gereja Australia 
Menolak." Msn.Com.

Jolley, Daniel, and Jenny L. Paterson. "Pylons Ablaze: Examining the Role of 5G COVID-19 Conspiracy Beliefs and Support for Violence." British Journal of Social Psychology 59, no. 3 (2020): 628-640.

Kozinets, R. V. Netnography: Doing Etnhograpic Research Online. London: Sage Publication, 2009.

- - - "The Field Behind The Screen: Using Netnography for Marketing Research in Online Communities." Journal of Marketing Research (2002): 61-72.

Kraybill, D. B. The Riddle of Amish Culture. Johns Hopkins University Press, 2001.

Larson, Heidi. “Underlying Issues Are Key to Dispelling Vaccine Doubts.” Bulletin of the World Health Organization, February 2014.

Nyahuma, Blessing, and Joachim Kügler. "Apocalypse Then and Now! - Political and Religious Interpretations of Tribulations in Apocalyptic Mind-Sets." Pharos Journal of Theology 102 (2021).

Omer SB, Pan WK, Halsey NA, and et al. "Non-Medical Exemptions to School Immunization Requirements: Secular Trends and Association of State Policies with Pertussisincidence." JAMA 296, no. 14 (2006): 1757-1763.

Omer SB, Richards JL, Ward M, and BednarczykRA. "Vaccination Policies and Rates of ExEmption from Immunization, 2005-2011." N Engl J Med. 367, no. 12 (2012): 1170-1171.

Omer SB, Salmon DA, Orenstein WA, deHart MP, and Halsey N. "Vaccine Refusal, Mandatory Immuni-Zation, and the Risks of Vaccine-Preventable Diseases." $N$ Engl J Med 360, no. 19 (2009): 1981-1988.

Pelčić, Gordana, Silvana Karačić, Galina L. Mikirtichan, Olga I. Kubar, Frank J. Leavitt, Michael Cheng Tek Tai, Naoki Morishita, Suzana Vuletić, and Luka Tomašević. "Religious Exception for Vaccination or Religious Excuses for Avoiding Vaccination." Croatian Medical Journal 57, no. 5 (2016): 516-521.

Ruijs, Wilhelmina Lm, Jeannine La Hautvast, Giovanna Van Ijzendoorn, Wilke Jc Van Ansem, Glyn Elwyn, Koos Van Der Velden, and Marlies Ejl Hulscher. "How Healthcare Professionals Respond to Parents with Religious Objections to Vaccination: A Qualitative Study." BMC Health Services Research 12, no. 1 (2012).

Saputro, Febrianto Adi. "Survei: 51,1 Persen Masyarakat Indonesia Percaya Vaksin | Republika Online." Republika.Com.

Stein, Rachel E, Katie E Corcoran, Corey J Colyer, Annette M Mackay, and Sara K Guthrie. "Closed but Not Protected : Excess Deaths Among the Amish and Mennonites During the COVID - 19 Pandemic." Journal of Religion and Health, no. 0123456789 (2021).

Toni, Ahmad. “Studi Netnografi ‘Komunitas Anti Islam' Di Media Online Facebook.” In Prosiding SNaPP2017 Sosial, Ekonomi, Dan Humaniora, 127-138, 2017.

Wielders CC, van Binnendijk RS, Snijders BE, Tipples GA, Cremer J, Fanoy E, Dolman S, et al. "Mumps Epidemic in Orthodox Religious Low-Vaccination Communities in the 
Netherlands and Canada, 2007 to 2009." Euro Surveill 16, no. pii (2011): 19989 undefined.

Zengarini, Lisa. “US Bishops Express Moral Concern over 'Johnson \& Johnson' Vaccine Vatican News." Vaticannews.Va.

“Covid: Vatican Says Coronavirus Vaccines 'morally Acceptable' - BBC News.” Bbc.Com. 